\title{
The Assay of Ascorbic Acid in Serum Is Not Affected by Physiological Concentrations of Transferrin and Hemoglobin
}

\author{
Hiroshi IHARA $^{1}$, Yoshio SHINO ${ }^{1}$, Naotaka HASHIZuME ${ }^{1}$, Akiko HIRANO ${ }^{2}$ \\ and Mitsumasa OKADA ${ }^{2}$ \\ ${ }^{1}$ Department of Laboratory Medicine, Ohashi Hospital, School of Medicine, and ${ }^{2}$ Department of Biomolecular \\ Science, Faculty of Science, Toho University, 2-17-6, Ohashi, Meguro-ku, Tokyo 153-8515, Japan
}

(Received January 29, 2003)

\begin{abstract}
Summary Transferrin and hemoglobin have been reported to oxidize L-ascorbic acid (AA) in vitro. The aim of this study was to determine whether or not physiological concentrations of serum transferrin (reference range 22-45 $\mu \mathrm{mol} / \mathrm{L}$ ) and hemoglobin (reference range $0-3.0 \mu \mathrm{mol} / \mathrm{L}$ ) interfer with the measurement of AA in the serum. Transferrin (33 to $41 \mu \mathrm{mol} / \mathrm{L})$ and hemoglobin $(1.9 \mu \mathrm{mol} / \mathrm{L})$ added to freshly pooled serum significantly decreased measured AA in the serum $(p<0.05)$. However, we found that the magnitude of the decrease in AA due to transferrin at concentrations within the reference range or up to $80 \mu \mathrm{mol} / \mathrm{L}$ was inconsequential, and had no clinical importance in diagnosing a low AA concentration. Hemoglobin at concentrations within the reference range had little affect on the serum AA measurement. However, when serum specimens were stored at $4^{\circ} \mathrm{C}$ for more than $1.5 \mathrm{~h}$, the magnitude of the decrease in AA due to hemoglobin at physiological concentrations may cause a misleading clinical diagnostic evaluation of low AA concentration.

Key Words ascorbic acid, transferrin, hemoglobin, serum, hemolysis
\end{abstract}

Vitamin C (L-ascorbic acid, AA) is an essential micronutrient required for the normal metabolic functioning of the human body. Because humans have lost the ability to synthesize AA owing to a mutation in the gene coding for L-gulono- $\gamma$-lactone oxidase, AA must be obtained through the diet. Currently, AA nutritional status is assessed by measuring the AA concentration in the serum or plasma (1). AA in the serum is unstable: dissolved oxygen, temperatures above $4^{\circ} \mathrm{C}$, light, $\mathrm{pH}$ above 5.0, and transition metal ions can result in the oxidation of AA to biologically inactive 2,3-diketo-Lgulonic acid via dehydro-L-ascorbic acid (DHA). AA is also reported to be oxidized to DHA by transferrin and hemoglobin (2). Transferrin, an iron transport protein, is present in normal serum. A minute quantity of hemoglobin is normally released into the serum by the destruction of erythrocytes. Our goal here is to determine whether or not transferrin and hemoglobin in the serum at physiological concentrations interfere with the determination of serum AA.

\section{Materials and Methods}

Human holo-transferrin (Sigma Chemical, catalog no. T-3309, iron content 300-600 mg/g protein, St. Louis, MO, USA) in amounts of 300 to $1400 \mathrm{mg}$ was dissolved in $100 \mathrm{~mL}$ of distilled water. Human hemoglobin (Sigma Chemical, catalog no. H-7379, St. Louis, MO, USA) in amounts of 25 to $400 \mathrm{mg}$ was also dissolved in $100 \mathrm{~mL}$ of distilled water. One part of these solutions was mixed with nine parts of a fresh serum pool from healthy

E-mail: ihara-1@cam.hi-ho.ne.jp volunteers to give the concentrations shown in Tables 1 and 2 . The unsupplemented pooled serum contained $27 \mu \mathrm{mol} / \mathrm{L}$ of transferrin and $0.4 \mu \mathrm{mol} / \mathrm{L}$ of hemoglobin.

AA concentrations were measured by two ascorbate oxidase (ASO) methods. The first method involved protein precipitation with metaphosphoric acid and the use of an ASO method described elsewhere (3). ASO converts all AA to DHA, and the resulting DHA was measured using $o$-phenylenediamine as the chromogen. The second method was the same as the first, but there was no deproteinization step (1). ASO (Amano III/ $\mathrm{ASO}^{\circledR}$, abbreviated as ASO-3, Amano Pharmaceutical Co., Ltd., Nagoya, Japan) converts AA to DHA and hydrogen peroxide. The resulting hydrogen peroxide was measured using 10-N-methylcarbamyol-3,7-dimethylamino-10H-phenothiazine in the presence of horseradish peroxidase.

Serum concentrations of transferrin were measured nephelometrically with the use of a Dade Behring BN ProSpec System. Serum concentrations of hemoglobin were measured with a spectrophotometric scanning technique at 415, 450 and $700 \mathrm{~nm}$ (4). The data were analyzed using Student's t-test, and differences of $p<0.05$ were considered to be statistically significant.

\section{Results and Discussion}

Tables 1 and 2 show the AA concentrations in serum enriched with increasing amounts of transferrin and hemoglobin. The AA concentrations of the supplemented pools analyzed without deproteinization (ASO3 method) were, on average, $2.5 \%$ lower than those in 
Table 1. Effect of transferrin on oxidation of AA.

\begin{tabular}{ccc}
\hline $\begin{array}{c}\text { Transferrin, } \\
\mu \mathrm{mol} / \mathrm{L}\end{array}$ & $\begin{array}{c}\text { AA in deproteinized } \\
\text { serum, } \mu \mathrm{mol} / \mathrm{L}^{\mathrm{a}}\end{array}$ & $\begin{array}{c}\text { AA by direct analysis } \\
\text { of serum, } \mu \mathrm{mol} / \mathrm{L}^{\mathrm{a}}\end{array}$ \\
\hline $27^{\mathrm{f}}$ & $82.6 \pm 0.3(100)^{\mathrm{b}}$ & $79.5 \pm 0.3(100)^{\mathrm{b}}$ \\
33 & $81.1 \pm 0.7^{\mathrm{c}}(98)$ & $78.2 \pm 0.7^{\mathrm{c}}(98)$ \\
41 & $81.8 \pm 0.3^{\mathrm{c}}(99)$ & $77.1 \pm 0.9^{\mathrm{c}}(97)$ \\
55 & $80.5 \pm 1.2^{\mathrm{c}}(97)$ & $77.5 \pm 0.9^{\mathrm{c}}(97)$ \\
83 & $79.2 \pm 0.9^{\mathrm{e}}(96)$ & $77.9 \pm 0.9^{\mathrm{c}}(98)$ \\
144 & $76.7 \pm 0.6^{\mathrm{e}}(93)$ & $74.1 \pm 1.8^{\mathrm{d}}(93)$ \\
\hline
\end{tabular}

${ }^{a}$ Values are mean \pm SD of three experiments.

${ }^{b}$ Percent of the original concentration is in the parentheses.

${ }^{\mathrm{c}}$ Significantly $(p<0.05)$ lower than the values at 27 $\mu \mathrm{mol} / \mathrm{L}$ of transferrin.

d Significantly $(p<0.01)$ lower than the values at 27 $\mu \mathrm{mol} / \mathrm{L}$ of transferrin.

${ }^{\text {e }}$ Significantly $(p<0.001)$ lower than the values at 27 $\mu \mathrm{mol} / \mathrm{L}$ of transferrin.

f $27 \mu \mathrm{mol} / \mathrm{L}$ was the endogenous transferrin concentration.

Table 2. Effect of hemoglobin on oxidation of AA.

\begin{tabular}{lcc}
\hline $\begin{array}{c}\text { Hemoglobin, } \\
\mu \mathrm{mol} / \mathrm{L}\end{array}$ & $\begin{array}{c}\text { AA in deproteinized } \\
\text { serum, } \mu \mathrm{mol} / \mathrm{L}^{\mathrm{a}}\end{array}$ & $\begin{array}{c}\text { AA by direct analysis } \\
\text { of serum, } \mu \mathrm{mol} / \mathrm{L}^{\mathrm{a}}\end{array}$ \\
\hline $0.4^{\mathrm{e}}$ & $82.2 \pm 0.3(100)^{\mathrm{b}}$ & $79.5 \pm 0.3(100)^{\mathrm{b}}$ \\
0.7 & $81.9 \pm 1.0(100)$ & $79.2 \pm 0.9(100)$ \\
1.1 & $81.9 \pm 0.9(100)$ & $77.9 \pm 0.8^{\mathrm{c}}(98)$ \\
1.9 & $80.6 \pm 0.5^{\mathrm{d}}(98)$ & $77.6 \pm 0.8^{\mathrm{d}}(98)$ \\
3.4 & $79.7 \pm 1.1^{\mathrm{d}}(97)$ & $77.0 \pm 0.8^{\mathrm{d}}(97)$ \\
6.6 & $77.3 \pm 1.6^{\mathrm{d}}(94)$ & $75.8 \pm 1.3^{\mathrm{d}}(95)$ \\
\hline
\end{tabular}

${ }^{a}$ Values are mean $\pm S D$ of three experiments.

${ }^{b}$ Percent of the original concentration is in the parentheses.

${ }^{c}$ Significantly $(p<0.05)$ lower than the values at 0.4 $\mu \mathrm{mol} / \mathrm{L}$ of hemoglobin.

d Significantly $(p<0.01)$ lower than the values at 0.4 $\mu \mathrm{mol} / \mathrm{L}$ of hemoglobin.

${ }^{\mathrm{e}} 0.4 \mu \mathrm{mol} / \mathrm{L}$ was the endogenous hemoglobin concentration.

deproteinized serum (ASO method); there was a good correlation between the AA values by the two methods $(r=0.97, \mathrm{p}<0.001)$. The difference may be due to the presence of endogenous DHA in the serum. Dhariwal et al. (5) reported that DHA could not be detected in fresh human serum, but that it could be made to appear in serum specimens processed under oxidizing conditions. The ASO method measures AA together with DHA, but the ASO-3 method does not measure DHA (1). The difference was increased by storage in the presence of transferrin or hemoglobin, and was significantly correlated with the DHA concentration $(r=0.68, \mathrm{p}<0.05)$. In this study, the DHA concentration in deproteinized serum was roughly estimated using the ASO method, with the ASO reagent replaced by phosphate buffer.

Increasing concentrations of transferrin and hemoglobin decreased the measured AA concentrations in

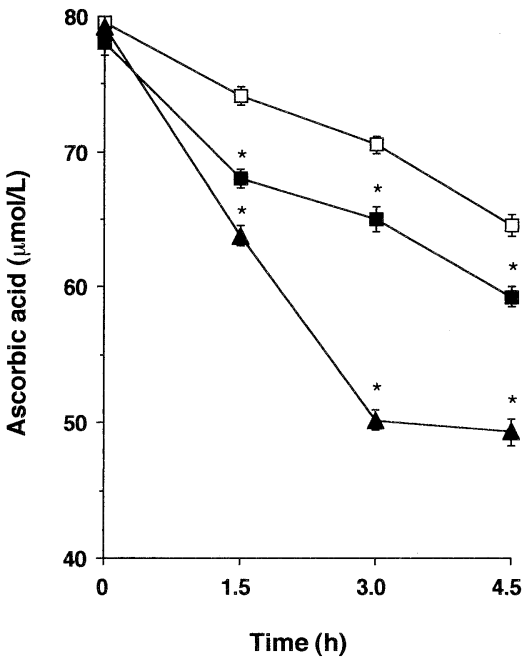

Fig. 1. Effect of incubation time on the oxidation of serum $\mathrm{AA}$ stored at $4^{\circ} \mathrm{C}$ in the dark. The values are mean $\pm \mathrm{SD}$ of three experiments determined with the ASO-3 method. Open squares, AA concentrations in original untreated serum pool containing $27 \mu \mathrm{mol} / \mathrm{L}$ of transferrin and $0.4 \mu \mathrm{mol} / \mathrm{L}$ of hemoglobin; solid squares, AA concentrations in serum containing $83 \mu \mathrm{mol} / \mathrm{L}$ of transferrin and $0.4 \mu \mathrm{mol} / \mathrm{L}$ of hemoglobin; solid triangles, AA concentrations in serum containing $0.7 \mu \mathrm{mol} / \mathrm{L}$ of hemoglobin and $27 \mu \mathrm{mol} / \mathrm{L}$ of transferrin. The asterisk $(*)$ denotes a decrease of AA that was significantly larger than that in the original serum pool $(p<0.05)$.

serum with or without deproteinization. Transferrin concentrations of 33 to $41 \mu \mathrm{mol} / \mathrm{L}$, values that were within the reference range of 22 to $45 \mu \mathrm{mol} / \mathrm{L}$, significantly decreased the observed AA concentrations as compared with those in serum not supplemented with transferrin $(p<0.05)$. Koshiishi et al. (2) proposed that this decrease is owing to the ferric ion released from transferrin in acidified serum and the subsequent oxidation of AA to DHA by ferric ions. Furthermore, hemoglobin concentrations of $1.9 \mu \mathrm{mol} / \mathrm{L}$, a value that was within the reference range of 0 to $3.0 \mu \mathrm{mol} / \mathrm{L}$, significantly decreased the observed AA concentrations as compared with those in the serum not supplemented with hemoglobin $(p<0.05)$. With $3.4 \mu \mathrm{mol} / \mathrm{L}$ of hemoglobin, the decrease in AA was inconsiderable, at less than $3 \%$ of the original concentration. Although the decrease in AA due to hemoglobin was reported to be caused by oxygen released from hemoglobin during acidic deproteinization (2), we found that increasing concentrations of hemoglobin decreased the measured AA concentrations in serum with or without deproteinization.

When the transferrin- or hemoglobin-supplemented serum, with a transferrin concentration of $83 \mu \mathrm{mol} / \mathrm{L}$ or a hemoglobin concentration of $0.7 \mu \mathrm{mol} / \mathrm{L}$, was stored at $4^{\circ} \mathrm{C}$ in the dark, the AA concentrations determined by the ASO-3 method decreased with time significantly faster than did those of the original serum having $27 \mu \mathrm{mol} / \mathrm{L}$ transferrin and $0.4 \mu \mathrm{mol} / \mathrm{L}$ hemoglobin $(p<0.05$, Fig. 1). The rate of decrease of AA was 

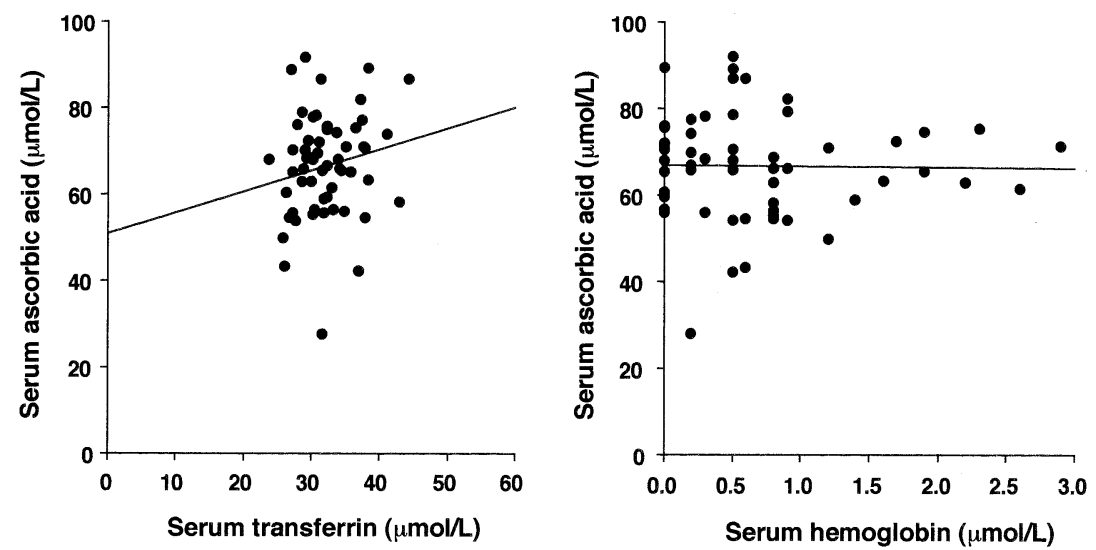

Fig. 2. Comparison of serum transferrin and hemoglobin concentrations and serum AA concentrations in 58 sera from healthy women. AA concentrations were determined by the ASO-3 method. For, transferrin, $r=0.18(p>0.05)$; the least squares equation is $\mathrm{Y}=0.48 \mathrm{X}+51$. For, hemoglobin, $r=-0.02(p<0.05)$; the least squares equation is $\mathrm{Y}=-0.29 \mathrm{X}+67$.

$3.2 \mu \mathrm{mol} / \mathrm{L} / \mathrm{h}, 4.3 \mu \mathrm{mol} / \mathrm{L} / \mathrm{h}$ and $6.9 \mu \mathrm{mol} / \mathrm{L} / \mathrm{h}$ in the original serum, transferrin $(83 \mu \mathrm{mol} / \mathrm{L})$-supplemented serum, and hemoglobin $(0.7 \mu \mathrm{mol} / \mathrm{L})$-supplemented serum, respectively. Therefore, we demonstrate that AA could be oxidized not only by ferric ions released from transferrin, but also oxidized directly by transferrin. In addition, AA was revealed to be oxidized directly by hemoglobin under neutral conditions.

Because serum concentrations of transferrin did not exceed $70 \mu \mathrm{mol} / \mathrm{L}$ in any clinical specimens, and the decreases in AA concentration at this transferrin level were less than $5 \%$ of the original concentration, we concluded that transferrin at concentrations within the reference range or up to about $80 \mu \mathrm{mol} / \mathrm{L}$ had little affect on AA concentration in the serum. Serum hemoglobin at $0.7 \mu \mathrm{mol} / \mathrm{L}$, which was a quarter of the reference range, did not affect the AA concentration when AA was measured within $1.5 \mathrm{~h}$ after serum specimens were obtained. However, this level of hemoglobin dropped significantly, $>30 \%$ of AA stored for $3 \mathrm{~h}$. Unfortunately, we could not visually identify the presence of hemoglobin (hemolysis) of less than $7.0 \mu \mathrm{mol} / \mathrm{L}$ in serum. Falsely lowered AA values resulting from storage may be a clinical diagnostic problem.

Indeed, no correlation was found $(r=0.18, p>0.05)$ when the serum transferrin values of 58 healthy women (ages 18-26 y) were compared with serum AA concentrations measured by the ASO-3 method $1.5 \mathrm{~h}$ after blood specimens were collected (Fig. 2). Elevated concentrations of transferrin were often observed in young women who had iron deficiency. Furthermore, there was no correlation between serum AA concentrations and serum hemoglobin concentrations in the same volunteers $(r=-0.02, p>0.05)$.

\section{REFERENCES}

1) Ihara H, Hashizume N, Hirano A, Okada M. 2001. Ascorbic acid analysis in biological samples. Rinsho Kensa 45: 1104-1111 (in Japanese).

2) Koshiishi I, Mamura Y, Liu J, Imanari T. 1998. Evaluation of an acidic deproteinization for the measurement of ascorbate and dehydroascorbate in plasma samples. Clin Chem 44: 863-868.

3) Ihara H, Shino Y, Aoki Y, Hashizume N, Minegishi N. 2000. A simple and rapid method for the routine assay of total ascorbic acid in serum and plasma using ascorbate oxidase and $o$-phenylenediamine. J Nutr Sci Vitaminol 46: 321-324.

4) Fairbanks VF, Klee GG. 1994. Measurement of plasma hemoglobin, oxyhemoglobin, and methemalbumin. In: Tiets Textbook of Clinical Chemistry (Burtis CA, Ashwood ER, eds), 2nd ed, p 2022-2025. WB Saunders Company, Philadelphia.

5) Dhariwal KR, Hartzell WO, Levine M. 1991. Ascorbic acid and dehydroascorbic acid measurements in human plasma and serum. Am J Clin Nutr 54: 712-716. 